\title{
Seussapex, a new genus of lecanicephalidean tapeworm (Platyhelminthes: Cestoda) from the stingray genus Himantura (Myliobatiformes: Dasyatidae) in the Indo-West Pacific with investigation of mode of attachment
}

\author{
Kirsten Jensen ${ }^{1}$ and Shelbi L. Russell ${ }^{2}$ \\ ${ }^{1}$ Department of Ecology and Evolutionary Biology, and the Biodiversity Institute, University of Kansas, Lawrence, Kansas, USA; \\ ${ }^{2}$ Department of Organismic and Evolutionary Biology, Harvard University, Cambridge, Massachusetts, USA
}

\begin{abstract}
A new lecanicephalidean genus, Seussapex gen. n., is erected for specimens collected from stingrays from the Indo-West Pacific resembling the little known species Tenia [sic] narinari MacCallum, 1917 from the spotted eagle ray, Aetobatus narinari (Euphrasen). Members of this new genus are unique in their possession of a multi-tiered apical structure comprising a bipartite apical modification of the scolex proper, and an externally bipartite apical organ with anterior and posterior glandular compartments internally. The appearance of the scolex varies dramatically depending on state of protrusion and/or evagination of these different parts which appear to be able to function independently. Seussapex karybares sp. n. parasitizing Himantura uarnak 2 (sensu Naylor et al., 2012) in northern Australia is described as the type species and Tenia [sic] narinari is transferred to the new genus. The two species differ in scolex length and width of the posterior dome-shaped portion of the apical organ. Histological sections of scoleces stained using the periodic acid-Schiff (PAS) reaction showed the surface of the anterior part of the apical organ and the anterior glandular compartment to stain PAS positive, suggesting a chemical mode of attachment to the host's intestinal mucosal surface. Extensive collecting efforts of stingrays in the Indo-West Pacific shows Seussapex gen. n. to be restricted to species of Himantura Müller et Henle and suggests additional diversity in this group of hosts. In addition, the host identity of Seussapex narinari (MacCallum, 1917) comb. $n$. is called into question.
\end{abstract}

Keywords: new species, elasmobranchs, apical organ, scanning electron microscopy, PAS

Almost a century ago, MacCallum (1917) described the tapeworm Tenia [sic] narinari MacCallum, 1917 from the spotted eagle ray, Aetobatus narinari (Euphrasen) (Myliobatiformes: Myliobatidae), putatively collected from Jakarta (as Batavia) in the Indian Ocean. Unfortunately, his description was brief, included only the scolex, and was based on a single incomplete specimen deposited in the United States National Parasite Collection (USNPC No. 35813). MacCallum (1917) recognized the unusual protrusible nature of the scolex of this worm, and described and figured its morphology in detail (Fig. 1A,B). However, he provided little proglottid information.

Despite its highly unusual scolex, Tenia [sic] narinari has not been reported since its original description and its morphology is not fully understood. Furthermore, its taxonomic identity is somewhat problematic. Although MacCallum (1917) was the first to use the name Tenia [sic], it is likely to be a misspelling of the cyclophyllidean genus, Taenia Linnaeus, 1758; there is no indication that MacCallum (1917) intended to erect a new genus for this species. Clearly, this taxon is in need of further study.
Fieldwork over the past 15 years focused on elasmobranchs from the Indo-West Pacific has resulted in the collection of tapeworms from the spiral intestines of a wide diversity of stingray species. This material includes numerous specimens from at least eight stingray species in the genus Himantura Müller et Henle in Australia, Borneo and the Solomon Islands with a scolex morphology like that described and illustrated by MacCallum (1917) for Tenia [sic] narinari. Examination of this material along with the type specimen of Tenia [sic] narinari supports the notion that this taxon is a member of the order Lecanicephalidea, rather than Cyclophyllidea.

However, this material substantially deviates from the diagnoses of all 18 lecanicephalidean genera currently recognized as valid (Euzet 1994, Jensen 2005, Cielocha and Jensen 2011, Jensen et al. 2011, 2013, Koch et al. 2012). As a consequence, a new genus is erected below, a new species from Himantura uarnak 2 (sensu Naylor et al. 2012) from Australia is described to serve as its type, and Tenia [sic] narinari is transferred to the new genus. In addition, the mode of attachment employed by these

Address for correspondence: K. Jensen, Department of Ecology and Evolutionary Biology, and the Biodiversity Institute, University of Kansas, 1200 Sunnyside Ave., Lawrence, KS 66045, USA. Phone: +1 785864 5826; Fax: +1 785864 5860; E-mail: jensen@ku.edu 
Table 1. Himantura species and specimens with their locality data known to host Seussapex. Note: Host accession number in bold indicate verified host identifications sensu Naylor et al. (2012).

\begin{tabular}{|c|c|}
\hline Host species & Collecting localities and Host Accession Nos.* \\
\hline $\begin{array}{l}\text { Himantura leoparda } \\
\text { Manjaji-Matsumoto et Last }\end{array}$ & NT, Australia: east of Wessel Islands ( $\left(11^{\circ} 17^{\prime} 44^{\prime \prime} \mathrm{S} ; 136^{\circ} 59^{\prime} 48^{\prime \prime E}\right)$ (NT-32, NT-117) \\
\hline $\begin{array}{l}\text { Himantura pastinacoides } \\
\text { (Bleeker) }\end{array}$ & 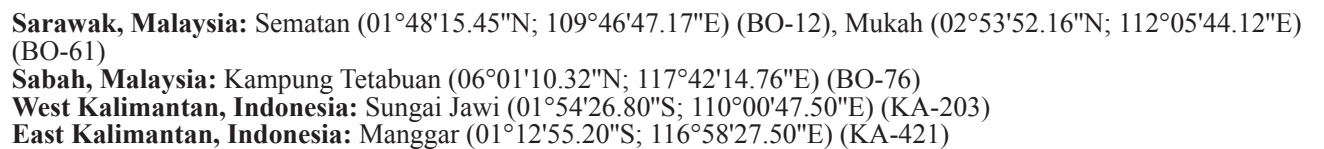 \\
\hline Himantura pastinacoides 2 & Sabah, Malaysia: Kampung Tetabuan $\left(06^{\circ} 01^{\prime} 10.32^{\prime \prime N}\right.$; $\left.117^{\circ} 42^{\prime} 14.76^{\prime \prime E}\right)$ (BO-113) \\
\hline $\begin{array}{l}\text { Himantura uarnacoides } \\
\text { (Bleeker) }\end{array}$ & 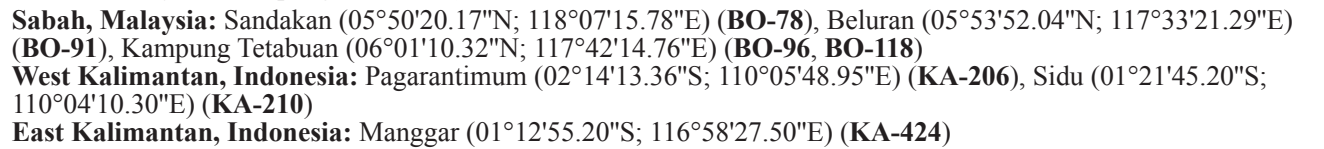 \\
\hline Himantura cf. uarnak & $\begin{array}{l}\text { Western Province, Solomon Islands: near Rarumana ( }\left(8^{\circ} 12^{\prime} 56.5^{\prime \prime} \text {; } 156^{\circ} 59^{\prime} 59.5^{\prime \prime E}\right)(\text { SO-4, SO-13) } \\
\text { South Kalimantan, Indonesia: Pagatan }\left(03^{\circ} 36^{\prime} 36.00^{\prime \prime} \text {; } 115^{\circ} 54^{\prime} 59.40^{\prime \prime E}\right)(\text { KA-71) }\end{array}$ \\
\hline Himantura uarnak 1 & $\begin{array}{l}\text { Sabah, Malaysia: Semporna }\left(04^{\circ} 28^{\prime} 44.09^{\prime \prime N} ; 118^{\circ} 37^{\prime} 00.57^{\prime \prime E}\right)\left(\text { BO-82), Lahad Datu }\left(05^{\circ} 01^{\prime} 17.46 " N \text {; }\right.\right. \\
\left.11^{\circ} 19^{\prime} 51.52^{\prime \prime E}\right)(\text { HBO-109) }\end{array}$ \\
\hline Himantura uarnak 2 & $\begin{array}{l}\text { NT Australia: Buffalo Creek at Lee Point }\left(12^{\circ} 20^{\prime} 11^{\prime \prime S} \text {; } 130^{\circ} 54^{\prime} 39^{\prime \prime} \text { E) (AU-139, AU-140, AU-141), }\right. \\
\text { Dundee Beach at Fog Bay }\left(12^{\circ} 45^{\prime} 33^{\prime \prime S} \text {; } 130^{\circ} 21^{\prime} 7^{\prime \prime E}\right)(\mathbf{A U}-55, \text { AU-58) } \\
\text { QLD, Australia: Weipa }\left(12^{\circ} 35^{\prime} 11^{\prime \prime S} \text {; } 141^{\circ} 42^{\prime} 34^{\prime \prime E}\right) \text { (CM03-3, CM03-13, CM03-14, CM03-24, CM03-25, CM03-57) }\end{array}$ \\
\hline Himantura uarnak 3 & 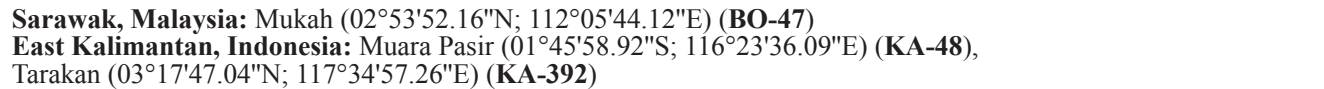 \\
\hline $\begin{array}{l}\text { Himantura undulata } \\
\text { (Bleeker) }\end{array}$ & Sabah, Malaysia: Tawau (04¹4'34.25"N; 11753'00.57"E) (BOD-69) \\
\hline
\end{tabular}

*see http://elasmobranchs.tapewormdb.uconn.edu for additional host specimens data (e.g. images, sex and size)

worms to attach to the mucosa of the spiral intestine using their complex scolex is discussed.

\section{MATERIALS AND METHODS}

The tapeworms examined in this study were collected from 31 stingrays representing at least eight species of Himantura (see Table 1). Stingrays were either caught using gill nets, hand spears or small trawls, and were mainly obtained from local fishermen or at fish markets. In the field, the body cavity of each stingray was opened with a ventral incision and the spiral intestine removed. The spiral intestine was opened with a longitudinal incision and fixed in 10\% seawater-buffered formalin and eventually transferred to $70 \%$ ethanol for storage. In the laboratory, spiral intestines were examined under a dissecting microscope and tapeworms encountered were removed.

All specimens prepared as whole-mounts were hydrated, stained in Delafield's hematoxylin, dehydrated in a graded ethanol series, cleared in methyl salicylate, and mounted in Canada balsam on glass slides. Semi-permanent mounts of eggs of the new species were prepared for light microscopy as follows. Gravid proglottids were placed in a $1: 1$ mixture of $70 \%$ ethanol and lactophenol and then broken open using insect pins. The eggs were isolated and mounted on a glass slide in lactophenol using clear nail polish to seal the edges of the coverslip.

Specimens prepared for scanning electron microscopy were hydrated, transferred to osmium tetraoxide overnight, dehydrated in a graded ethanol series, and placed in hexamethyldisilizane (HMDS) for $30 \mathrm{~min}$. The worms were allowed to air-dry and were mounted on aluminum stubs with double-sided adhesive carbon tape. The specimens were sputter coated with $\sim 35 \mathrm{~nm}$ of gold/palladium and examined with a Zeiss LEO 1550 field emission scanning electron microscope at the Microscopy and Analytical Imaging Laboratory, University of Kansas, Lawrence, USA. Terminology for microthrix forms follows Chervy (2009).
Specimens prepared for histological sections were embedded in paraffin and sectioned at $7 \mu \mathrm{m}$ intervals using an Olympus TBS CUT 4060 microtome. Sections were floated on 3\% sodium silicate on glass slides and allowed to air dry on a slide warmer. Sections were stained with hematoxylin/eosin (H \& E) or periodic acid-Schiff (PAS). For the H \& E protocol, sections were stained in Delafield's hematoxylin, counterstained with eosin, cleared in xylene, and mounted in Canada balsam on glass slides. The PAS protocol used was adapted from McManus' PAS staining protocol described in Sheehan and Hrapchak (1987). Sections were placed in two consecutive changes of xylene for $2 \mathrm{~min}$ each, hydrated in a graded series of ethanols and distilled water for $2 \mathrm{~min}$ each, immersed in periodic acid for 5 min, rinsed in 7 changes of distilled water, immersed in Schiff reagent for $20 \mathrm{~min}$, placed in very warm $\left(\sim 55^{\circ} \mathrm{C}\right)$ distilled water for $10 \mathrm{~min}$, washed in running tap water for $10 \mathrm{~min}$, counterstained in Delafield's hematoxylin for $1 \mathrm{~min}$, washed in running tap water for $10 \mathrm{~min}$, dehydrated in a graded series of ethanols, and mounted in Canada balsam on glass slides.

Whole mounts and histological sections were examined using a Zeiss Axioskop 2 Plus compound microscope. Light micrographs were taken using a Leica DFC480 digital camera and measurements were made using the image analysis software OpenLab Demo or the Leica Application Suite V3. In all cases, measurements of reproductive organs were taken from the posterior-most mature proglottids and are given in micrometres. Measurements are given as ranges followed in parentheses by the means, standard deviations, number of specimens examined, and total number of observations when more than one measurement was made per worm. Illustrations were made using a drawing tube attached to a Zeiss Axioskop 2 Plus. Museum abbreviations used are as follows: Institute of Parasitology, Academy of Sciences of the Czech Republic (IPCAS), České Budějovice, Czech Republic; Lawrence R. Penner Parasitology Collection (LRP), University 
of Connecticut, Storrs, Connecticut; Queensland Museum (QM), Brisbane, Queensland, Australia; United States National Parasite Collection (USNPC) in Beltsville, Maryland, USA.

\section{RESULTS}

\section{Seussapex gen. n.}

Diagnosis: Worms apolytic. Scolex extensive, consisting of scolex proper, bipartite apical modification of scolex proper, and bipartite apical organ housing two glandular compartments internally. Scolex proper with four acetabula in form of suckers. Apical modification of scolex proper cylindrical; posterior portion with conspicuous spinitriches, anterior rim invaginable; anterior portion devoid of spinitriches, invaginable. Apical organ variable in form; posterior part dome-shaped, retractable; anterior part knob-like, retractable and/or invaginable; glandular compartments arranged in tandem with anterior compartment connecting to anterior part of apical organ via numerous channels. Proglottids craspedote, non-laciniate. Testes 4, anterior to ovary, in single column, 1 layer deep. Vas deferens extensive, forming external seminal vesicle, extending from ootype region to cirrus sac. Cirrus sac pyriform, containing armed cirrus. Genital pores lateral, irregularly alternating. Ovary lobulated (4 dorsal and 4 ventral lobes), H-shaped in frontal view, tetralobed in cross section. Vagina weakly sinuous, extending from ootype region anterior along lateral to median margin of proglottid, opening into genital atrium posterior to cirrus sac. Vitellarium follicular; follicles lateral, arranged in 1 dorsal and 1 ventral column on each lateral margin of proglottid, essentially interrupted at level of ovary. Uterus saccate, extending along poral side of proglottid from anterior margin of ovary to posterior margin of anteriormost testis. Eggs with bipolar filaments. Parasites of Himantura (Dasyatidae) (with questionable record from Aetobatus Blainville [Myliobatidae]). Indian and Pacific Oceans.

Ty pe s pecies: Seussapex karybares sp. n.

Additional species: S. narinari (MacCallum, 1917) comb. $n$.

Etymology: Seussapex (apex - summit or top in Latin) is named for the resemblance of the apical structure of the scolex to characters (e.g. a certain cat) created by Dr. Seuss.

Remarks. Among elasmobranch tapeworms, the presence of an apical organ, a vagina that enters into the genital atrium posterior to the cirrus sac, and an extensive external seminal vesicle originating at the level of the ootype places this new genus within the Lecanicephalidea. The new genus differs from the 18 genera currently considered valid in the Lecanicephalidea (Euzet 1994, Jensen 2005, Cielocha and Jensen 2011, 2013, Jensen et al. 2011, Koch et al. 2012) in its possession of a scolex bearing a unique multi-tiered apical structure consisting of a bipartite partially invaginable apical modification of the scolex proper and a bipartite retractable and partially
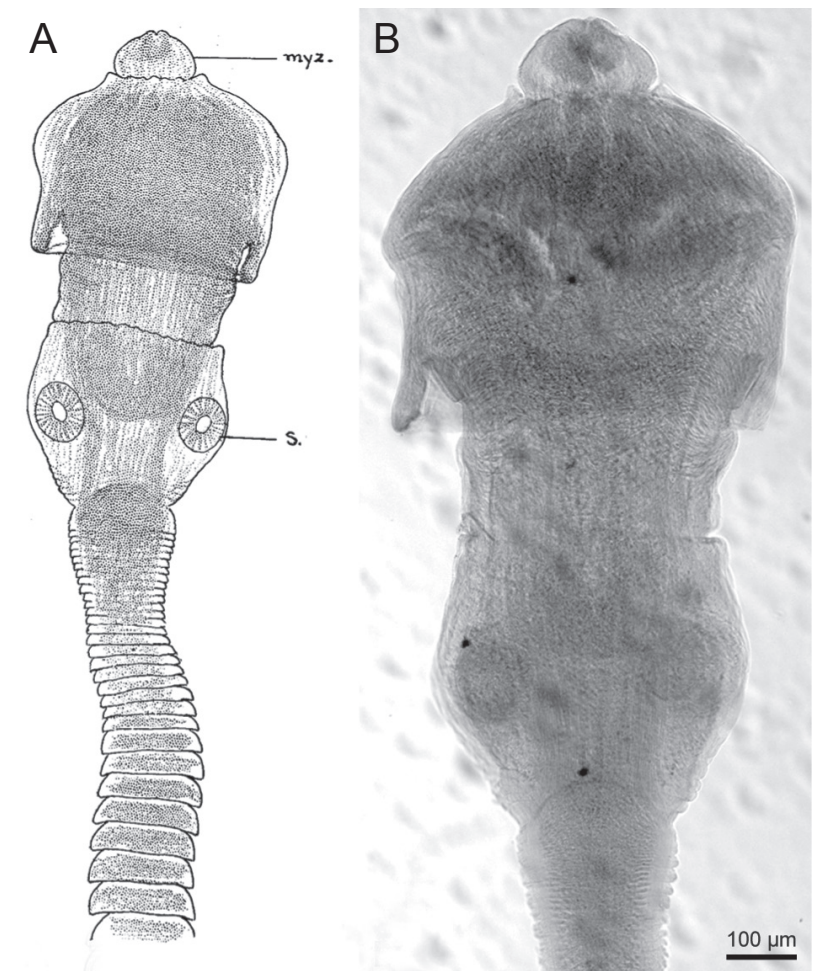

Fig. 1. Line drawing (A) and photo light micrograph (B) of Tenia [sic] narinari. A - figure 23 from original description by MacCallum (1917); B - scolex of type specimen (USNPC 35813).

invaginable apical organ with a tandem pair of glandular compartments. It can further be distinguished from $A b$ errapex Jensen, 2001; Collicocephalus Koch, Jensen et Caira, 2011; Elicilacunosus Koch, Jensen et Caira, 2011; Eniochobothrium Shipley et Hornell, 1906; Hexacanalis Perrenoud, 1931; Paraberrapex Jensen, 2001; Stoibocephalum Cielocha et Jensen, 2013; Tetragonocephalum Shipley et Hornell, 1905; and Tylocephalum Linton, 1890 in its possession of a single column of testes rather than two or more columns, and from Corrugatocephalum Caira, Jensen et Yamane, 1997 and Quadcuspibothrium Jensen, 2001 in its possession of testes in a single layer rather than two layers. Whereas the acetabula are in the form of suckers in Seussapex gen. n., they are bothridiate in Anteropora Subhapradha, 1955; Hornellobothrium Shipley et Hornell, 1906; and Rexapex Koch, Jensen et Caira, 2011. Its possession of an ovary that is tetralobed in cross section distinguishes Seussapex from Sesquipedalapex Jensen, Nikolov et Caira, 2011, which bears an ovary that is irregular in cross section. It also differs in this respect from Lecanicephalum Linton, 1890, which has an ovary that is bilobed in cross section. The proglottid anatomy of Seussapex is most similar to that of Polypocephalus Braun, 1878 but the genera differ conspicuously in the form of their apical features. Whereas the apical organ of members of Polypocephalus is divided into tentacles, that of Seussapex is not. Caira et al. (2014) 
included Seussapex in their molecular phylogeny under the name 'New genus 6'.

\section{Seussapex karybares sp. n.}

Figs. 2-5

Description (based on 31 specimens: 18 whole worms, 4 scolex longitudinal section series, 1 proglottid cross section series, 6 scolices prepared for SEM, and lactophenol preparation of eggs of 2 worms): Worms 4.3-10.2 $(7.1 \pm 1.8$; 18) $\mathrm{mm}$ long; maximum width at level of scolex; 35-63 $(47 \pm 8 ; 18)$ proglottids, apolytic. Scolex $368-638(506 \pm 81 ; 18)$ long by $259-417(344 \pm 44 ; 18)$ wide at level of acetabula, consisting of scolex proper (SP) with 4 acetabula, bipartite apical modification of scolex proper (AMSP) and bipartite apical organ (AO) with 2 glandular compartments internally. Acetabula in form of suckers, $72-106(87 \pm 8 ; 18 ; 36)$ in diameter. AMSP cylindrical; posterior portion with spinitriches, anterior rim invaginable; anterior portion lacking spinitriches, invaginable. Posterior part of AO dome-shaped, retractable; anterior part of AO knob-like, retractable and/or invaginable, with rugose surface; anterior-most glandular compartment PAS-positive, connected to anterior part of apical organ via numerous channels; posterior glandular compartment PAS-negative, surrounding anterior glandular compartment.

Both parts of AO (Fig. 3D,E), anterior portion of AMSP (Fig. 3F) and SP at level of and posterior to suckers (Fig. 3I) covered with acicular to capillifom filitriches. Sucker surfaces covered with small, hastate spinitriches and acicular filitriches (Fig. $3 \mathrm{H}$ ). Anterior region of SP and posterior region of AMSP covered with larger, hastate spinitriches increasing in density anteriorly and capilliform filitriches (Fig. 3G). Strobilar surfaces covered with capilliform filitriches increasing in diameter towards posterior margin of proglottid (Fig. 3J).

Cephalic peduncle absent. Proglottids craspedote; velum 19-31 $(25 \pm 3 ; 18)$ in length. Immature proglottids $29-51(38 \pm 6 ; 18)$ in number, initially wider than long, becoming longer than wide with maturity; posteriormost immature proglottid 148-292 (222 \pm 44 ; 18) long by $170-272(216 \pm 29 ; 18)$ wide. Mature proglottids 4-9 $(6 \pm 2 ; 18)$ in number, longer than wide; posteriormost mature proglottid 391-841 (525 $\pm 119 ; 18)$ long by $140-287(217 \pm 37 ; 18)$ wide. Gravid proglottids $0-6$ $(3 \pm 2 ; 18)$ in number, longer than wide; posterior-most gravid proglottid $659-1392(893 \pm 174 ; 17)$ long by $229-321(273 \pm 26 ; 17)$ wide. Testes 4 in number, 46-124 $(69 \pm 16 ; 18 ; 54)$ long by $54-149(99 \pm 21 ; 18 ; 54)$ wide, in single column in frontal view, 1 layer deep in cross section, extending from anterior margin of proglottid to anterior margin of ovary, slightly overlapping ovary. Vas deferens expanded to form external seminal vesicle, entering cirrus sac at its anterior margin. External seminal vesicle saccate, extending from ootype region to level anterior to cirrus sac. Cirrus sac pyriform, angled slightly anteriorly, 77-123 (103 $\pm 11 ; 14)$ long by 43-66 (51 \pm 7 ;
14) wide, containing coiled cirrus. Cirrus armed. Internal seminal vesicle present. Ovary posterior, consisting of 4 dorsal ( 2 anterior and 2 posterior) and four ventral ( 2 anterior and 2 posterior) lobes, essentially $\mathrm{H}$-shaped in frontal view, tetralobed in cross section (Fig. 4B), 96-167 $(125 \pm 20 ; 17)$ long by $90-179(141 \pm 21 ; 17)$ wide; lobes divided transversely at level of ovarian bridge; ovarian bridge slightly posterior to middle of ovary. Vagina thickwalled proximally, weakly sinuous, extending laterally to medially from ootype region to posterior margin of cirrus sac, entering into genital atrium posterior to cirrus sac; vaginal sphincter absent. Seminal receptacle present. Genital pores lateral, irregularly alternating, 50-63\% $(55 \pm 3 \% ; 18)$ of proglottid length from posterior end. Vitellarium follicular; follicles large, 20-73 (34 \pm 10 ; 18 ; 54) long by $23-96(53 \pm 16 ; 17$; 51) wide, lateral, arranged in 1 dorsal and 1 ventral column on each lateral margin of proglottid, extending from posterior margin of anteriormost testis to posterior margin of proglottid, interrupted by ovary. Uterus saccate, extending along poral side of proglottid from anterior margin of ovary to posterior margin of anteriormost testis; uterine duct not observed. Excretory ducts likely 4, 2 ducts on each lateral margin. Eggs 18-23 (19 \pm 2 ; 9) long by 15-19 (16 $\pm 1 ; 9)$ wide, with bipolar filaments.

\section{Scolex anatomy of Seussapex karybares gen. n. et sp. n.}

Characterization of the formal regions of a lecanicephalidean scolex (i.e. scolex proper, apical modification of the scolex proper, and apical organ), irrespective of protrusion and/or evagination state, was challenging for this new taxon given the complex nature of its scolex, but was essential for description of the new taxon. In combination, longitudinal sections and scanning electron microscopy served effectively to allow characterization of the various elements of the scolex. These elements and their associated terms are described in detail below in the context of the terminology employed by Caira et al. (1999, 2001).

The scolex consists of five distinct components that are identifiable externally: the scolex proper (SP) (Fig. 3A-C), an apical modification of the scolex proper (AMSP) consisting of an anterior portion and a posterior portion (Fig. $3 \mathrm{~A}-\mathrm{C}$ ), and an apical organ (AO) consisting of an anterior part (Fig. 3A,C) and a posterior part (Fig. 3A,D). The SP is the posterior-most region of the scolex and bears four suckers. The AMSP lies immediately anterior to the SP, is cylindrical in shape and is the most extensive component of the scolex. The posterior and anterior portions of the AMSP can be distinguished from one another in that the former bears conspicuous spinitriches whereas the latter does not (Fig. 3A-C). The anterior portion of the AMSP is invaginable into the posterior portion of the AMSP and ultimately the SP. Only the anterior rim of the posterior portion of the AMSP might also be invaginable. The AO lies immediately anterior to the AMSP (and is often the widest component of the scolex). The posterior part of 
A

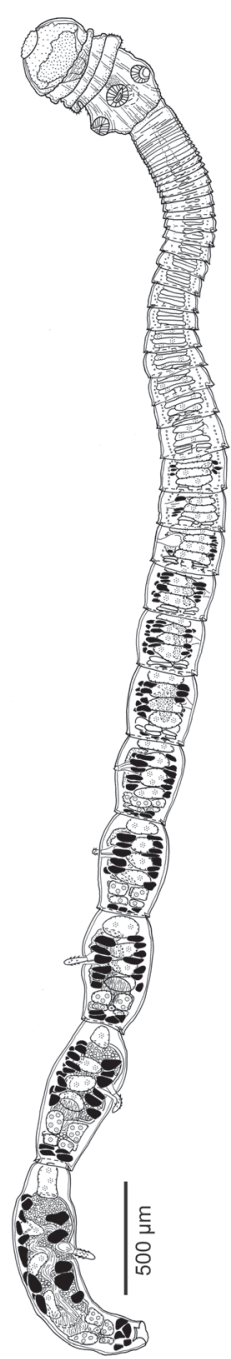

B
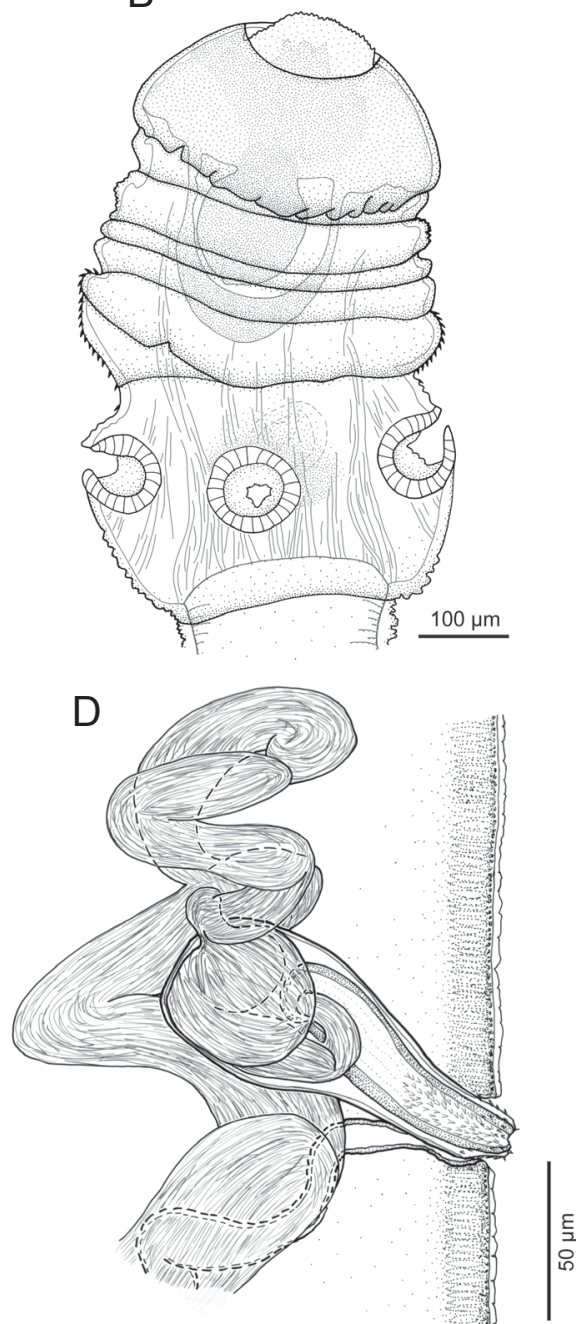

C

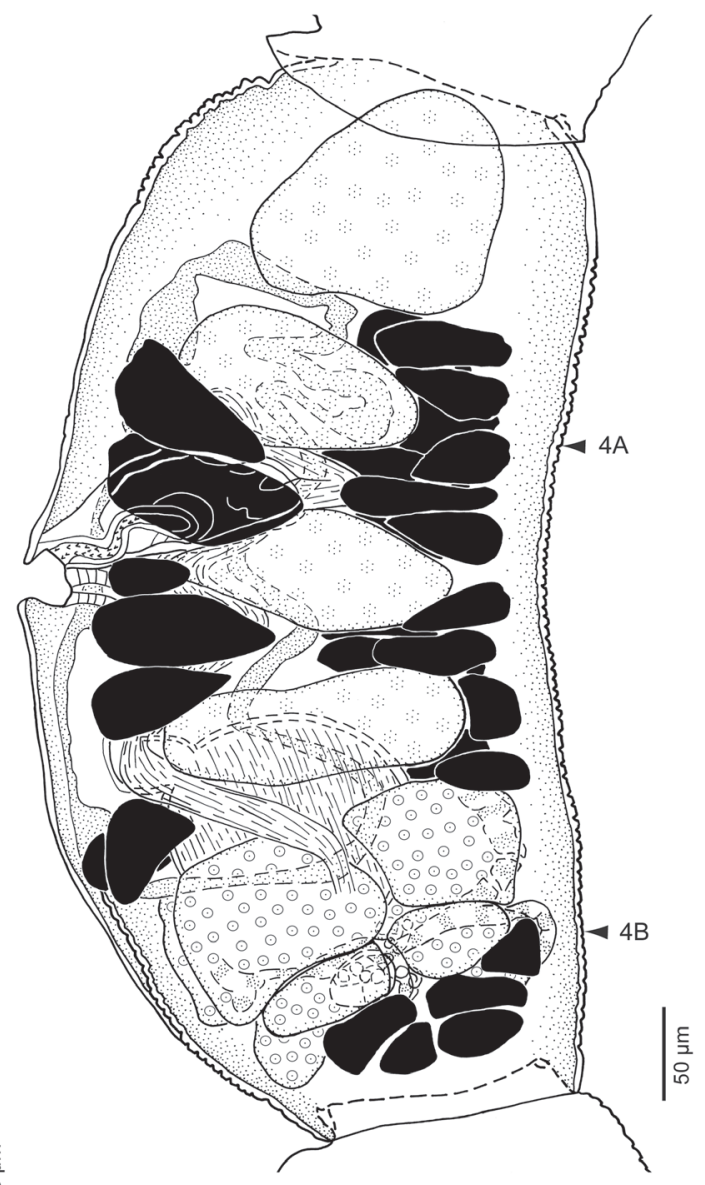

Fig. 2. Line drawings of Seussapex karybares gen. n. et sp. n. from Himantura uarnak 2 (sensu Naylor et al. 2012). A - whole worm; scolex in fully protruded/evaginated state; $\mathbf{B}$ - scolex, in fully protruded/evaginated state; $\mathbf{C}$ - mature proglottid (subterminal) (arrowheads indicate location of sections in Fig. 4A,B); D - detail of terminal genitalia.

the AO is dome-shaped and is retractable into the AMSP, and ultimately also the SP. The anterior part of the AO is knob-like in shape and can be retracted and/or invaginated into the posterior part of the AO, the AMSP, and ultimately also the SP. In the fully retracted state, only the $\mathrm{SP}$ and posteriormost region of the posterior portion of the AMSP are visible externally (Fig. 5A).

The posterior and anterior portions of the AMSP and the posterior and anterior parts of the $\mathrm{AO}$ are not protruded or evaginated in sequence, rather it appears they can function, and thus move in and out independently. For example, the anterior portion of the AMSP and the anterior part of the AO can be partially or fully evaginated while the posterior dome-shaped part of the AO remains retracted (Fig. 3C). Alternatively, the posterior dome-shaped part of the AO can be protruded while the anterior portion of the AMSP remains partially invaginated and the anterior part of the AO is fully retracted and/or invaginated (Fig. 3B).
Internally, the scolex houses two prominent glandular compartments arranged in tandem within the scolex; these are associated with the AO. The anterior compartment (G1 in Fig. 5) is teardrop-shaped when the AO and AMSP are fully or partially retracted and invaginated, respectively (Fig. 5A-C). However, it flattens to cover the entire anterior of the scolex when the AMSP is evaginated (Fig. 5D). Periodic acid-Schiff (PAS) staining revealed this glandular compartment to be highly PAS-positive (Fig. 5A-D). The second glandular compartment (G2 in Fig. 5) is posterior to the first, essentially surrounding it when the AO and AMSP are retracted and invaginated, respectively (Fig. 5A-C). However, it too flattens to lie below the first glandular compartment when the AMSP is evaginated (Fig. 5D). This compartment was PAS-negative (Fig. 5A-D).

The anterior glandular compartment appears to be much more intimately associated with both parts of the 

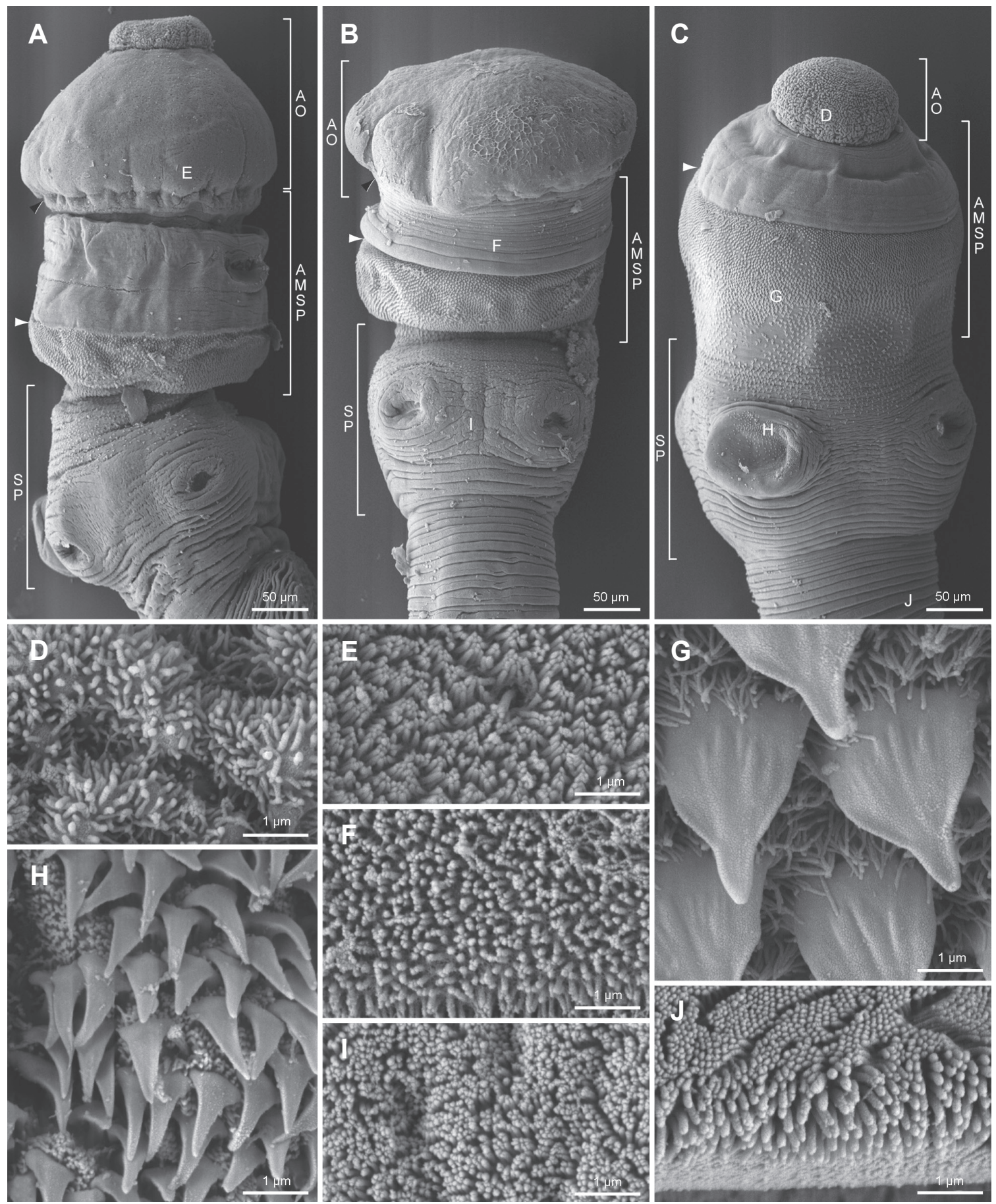

Fig. 3. Scanning electron micrographs of Seussapex karybares gen. n. et sp. n. from Himantura uarnak 2 (sensu Naylor et al. 2012). A - scolex in fully protruded/evaginated state showing scolex proper (SP) with suckers, posterior and anterior portion of apical modification of scolex proper (AMSP), and posterior dome-shaped and anterior knob-like part of apical organ (AO); B - scolex in partially protruded/evaginated state showing SP, posterior and anterior portion of AMSP, and posterior dome-shaped part of AO; anterior knoblike part of $\mathrm{AO}$ retracted and/or invaginated into posterior part of $\mathrm{AO} ; \mathbf{C}$ - scolex in partially protruded/evaginated state showing SP, posterior and anterior portion of AMSP, and anterior knob-like part of AO; posterior dome-shaped part of the AO retracted into AMSP; D - acicular filitrich or microvilli on anterior knob-like part of AO; $\mathbf{E}$ - acicular to capilliform filitriches on posterior dome-shaped part of AO; F - acicular to capilliform filitriches on anterior portion of AMSP; $\mathbf{G}$ - larger, hastate spinitriches and capilliform filitriches on posterior portion of AMSP; $\mathbf{H}$ - small, hastate spinitriches and acicular filitriches on sucker; $\mathbf{I}$ - acicular filitriches on scolex proper at level of suckers; $\mathbf{J}$ - capilliform filitriches on proglottid, increasing in length and diameter towards posterior margin of proglottid. $A b$ breviations: AMSP - apical modification of scolex proper; AO - apical organ; $\mathrm{SP}$ - scolex proper. White arrowheads indicate boundary between posterior and anterior portion of AMSP; black arrowheads indicate boundary between anterior portion of AMSP and posterior part of AO. In A-C, small letters indicate location of details shown in the respective figure. 

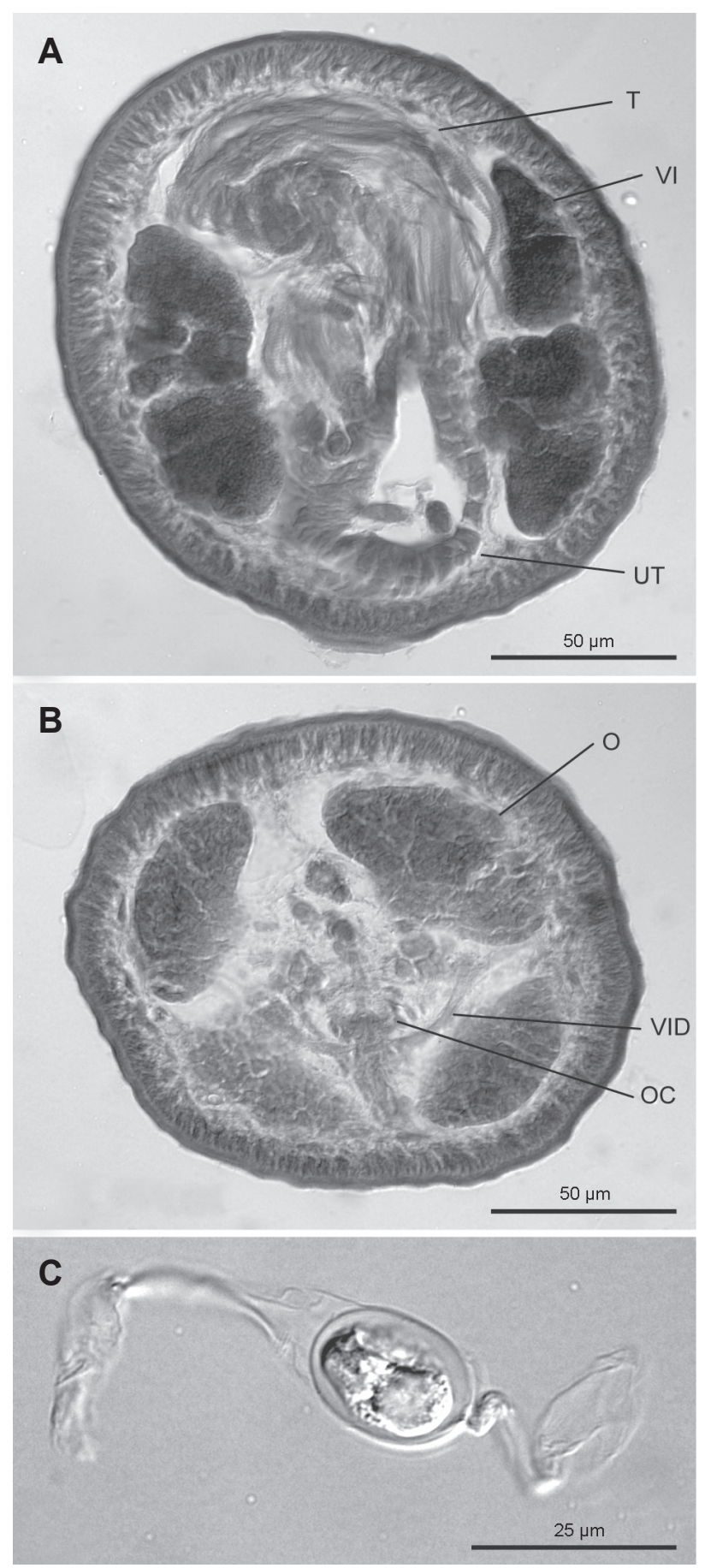

Fig. 4. Photomicrographs of Seussapex karybares gen. n. et sp. n. from Himantura uarnak 2 (sensu Naylor et al. 2012). $\mathbf{A}$ - cross section of mature proglottid at level anterior to cirrus sac; $\mathbf{B}$ - cross section of mature proglottid slightly posterior to ovarian bridge; $\mathrm{C}-$ egg with bipolar filaments. Abbreviations: $\mathrm{O}$ - ovary; OC - ovicapt; T - testis; UT - uterus; VI - vitelline follicle; VID - vitelline duct.

AO than the posterior glandular compartment. It appears to be in direct contact with the anterior part of the $\mathrm{AO}$ (Fig. 5B,C). In addition, numerous channels extending from the anterior glandular compartment appear to underlie the posterior dome-shaped part of the AO (e.g. Fig. 5A). Although conspicuous openings of these channels to the outside of the apical organ were not observed, the surface of the anterior part of the AO was intensely PAS-positive.

Because of the complex nature of the scolex and the fact that within the species, the scolices varied dramatically in size depending on the state of protrusion and/or evagination, only measurements of scolex total length, width of the scolex proper at the level of the suckers and width of the dome-shaped part of the apical organ were reliable, and are given in the description of the new species.

Ty p e host: Himantura uarnak 2 (sensu Naylor et al. 2012) (Myliobatiformes: Dasyatidae).

Other hosts: None.

Type locality: Buffalo Creek at Lee Point (12²0'11"S; $\left.130^{\circ} 54^{\prime} 39^{\prime \prime} \mathrm{E}\right)$, Northern Territory, Australia, Timor Sea.

Other 1 o c a liti es : Dundee Beach at Fog Bay $\left(12^{\circ} 45^{\prime} 33^{\prime \prime}\right.$; $\left.130^{\circ} 21^{\prime} 7^{\prime \prime E}\right)$, Northern Territory, Australia, Timor Sea; Weipa (12 $35^{\prime} 11^{\prime \prime S}$; 141 $\left.{ }^{\circ} 42^{\prime} 34^{\prime \prime E}\right)$, Queensland, Australia, Gulf of Carpentaria.

Site of infection: Spiral intestine.

Specimens deposited: QM G234324 (holotype) and QM G234320-G234323, G234325-234330 (ten paratypes: six whole worms, two scolex longitudinal section series, both PAS-stained, one proglottid cross section series and one lactophenol egg preparation including specimen voucher); IPCAS C-649 (one paratype); USNPC 107776-107779 (eight paratypes: six whole worms, one scolex longitudinal section series, PAS-stained, including strobilar voucher and one lactophenol egg preparation); LRP 8354-8362 (six paratypes: four whole worms, one scolex longitudinal section series, PAS-stained); six scoleces prepared for SEM strobila vouchers for three of those retained in the collection of KJ at the University of Kansas.

Ety mology: The specific epithet (karybares - top-heavy in Greek) was chosen to emphasize the disproportional large size of the apical structure compared to the remainder of the scolex.

Remarks. Specimens of Seussapex karybares sp. n. were found to parasitize 11 of the 13 specimens of Himantura uarnak 2 (sensu Naylor et al. 2012) examined. In general, members of this species were found to attach to the anteriormost chambers of the spiral intestine of their hosts.

Seussapex karybares (as 'New genus 6 n. sp. 1') was included in the molecular phylogeny of Caira et al. (2014). In their analyses, it grouped in a stable clade that also included members of Polypocephalus, Hornellobothrium and Anteropora. The disposition of the testes in a single column supports this grouping, possibly with the exception of Hornellobothrium (see Jensen 2005).

Seussapex narinari (MacCallum, 1917) comb. n.

Redescription (based on single type specimen whole mount of incomplete specimen with scolex, USNPC 35813): Worm at least $5.7 \mathrm{~mm}$ long; maximum 

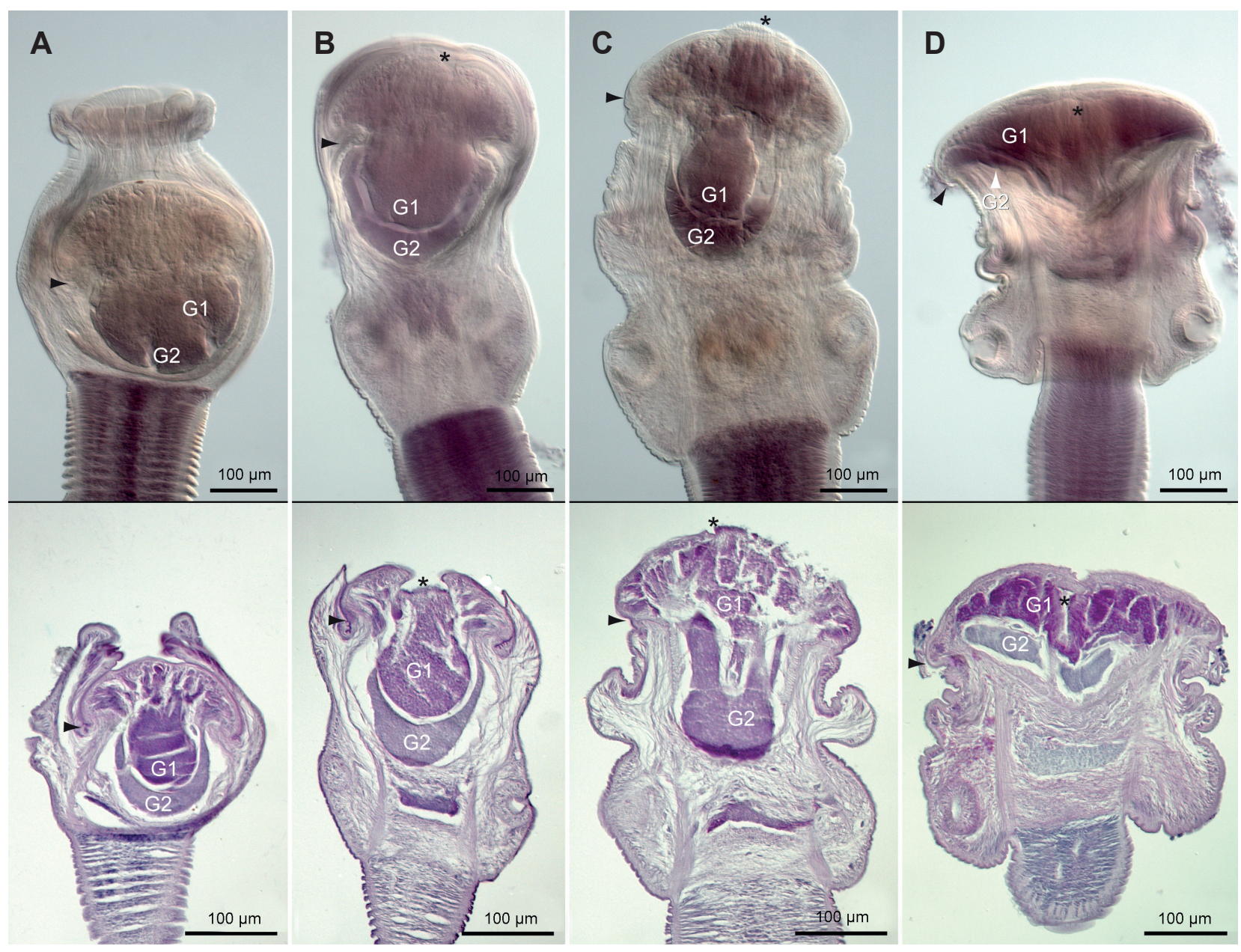

Fig. 5. Photomicrographs of whole-mounted scoleces at different stages of protrusion/evagination (top row) and corresponding histological longitudinal sections (PAS-stained) (bottom row) of Seussapex karybares gen. n. et sp. n. from Himantura uarnak 2 (sensu Naylor et al. 2012). Black arrowheads indicate boundary AMSP and AO. A - scolex in fully retracted/invaginated state; anterior glandular compartment of AO (G1) surrounded by posterior glandular compartment (G2), both retracted to level of scolex proper; B - scolex with partially evaginated anterior portion of AMSP and partially protruded posterior dome-shaped part of AO (black star indicates retracted anterior knob-like part of AO); G1 surrounded by G2, both retracted to essentially level of AMSP; $\mathbf{C}$ - scolex with partially evaginated anterior portion of AMSP and fully protruded posterior dome-shaped part of AO (black star indicates protruded/evaginated anterior knob-like part of AO); G1 covering almost entire anterior of scolex surrounded by G2; D - scolex with evaginated anterior portion of AMSP and protruded posterior dome-shaped part of AO (black star indicates invagined anterior knob-like part of AO); G1 covering entire anterior of scolex, lying above flattened G2.

width at level of scolex; proglottids 64 in number. Scolex 1070 long by 433 wide at level of AMSP, consisting of scolex proper bearing 4 acetabula, bipartite (?) AMSP, and bipartite $\mathrm{AO}$ with 2 glandular compartment internally. Acetabula in form of suckers, $103-105$ in diameter. AMSP cylindrical; anterior portion craspedote. Posterior part of AO dome-shaped, 578 wide; anterior part of $\mathrm{AO}$ knob-like, prominent.

Cephalic peduncle absent. Proglottids craspedote. Immature proglottids at least 64 in number, initially wider than long, becoming longer than wide with maturity; terminal immature proglottid 293 long by 222 wide. Testes 4 in number. Vagina entering genital atrium posterior to cirrus sac. Other features not observed.
Type host: Aetobatus narinari (Euphrasen), spotted eagle ray (Myliobatiformes: Myliobatidae).

Type locality: Not given in original description but label on type slide indicates Jakarta (as Batavia), Java, Indian Ocean.

Site of infection: Spiral intestine.

Material examined: USNPC 35813 (type specimen).

Remarks. A complete redescription of Seussapex narinari comb. $\mathrm{n}$. is not possible at this time given the limitations of the type specimen and that no new material was available for study. However, it is apparent that the type specimen is indeed a lecanicephalidean due to its possession of a vagina that opens into the genital atrium posterior to the cirrus sac and also the configuration of its apical 
organ. Seussapex narinari is fully consistent with the diagnosis of Seussapex established herein. However, it differs from the type of the genus, $S$. karybares, by its longer scolex $(1070 \mu \mathrm{m}$ vs 368-638 $\mu \mathrm{m})$ and wider posterior dome-shaped portion of the $\mathrm{AO}(578 \mu \mathrm{m} v s 312-407 \mu \mathrm{m})$. The obviously craspedote nature of the anterior portion of the AMSP in S. narinari could represent a speciesspecific feature. However, this remains to be seen given that some specimens of $S$. karybares were seen to have, to some extent, overlapping parts to their scolex.

The redescription of $S$. narinari presented here is generally consistent with MacCallum's description of this species with one exception. The actual total length of the specimen is $\sim 1 \mathrm{~mm}$ longer than reported by MacCallum (1917) (i.e. $7.0 \mathrm{~mm} v s 5.7 \mathrm{~mm}$ ). We should also note that MacCallum's (1917) illustration of the scolex of this species (Fig. 1) is superb and accurately represents the true likeness of the type specimen. Given that our current knowledge of $S$. narinari is based on a single specimen, a few generic features should be unambiguously confirmed based on new material using histological sections or scanning electron microscopy (e.g. the presence of dual glandular compartments or the boundary between the anterior and posterior portions of the AMSP). However, given its overall resemblance to $S$. karybares, membership in Seussapex is strongly supported.

\section{DISCUSSION}

The erection of the new lecanicephalidean genus broadens our concept of the morphological diversity of scolex forms exhibited by members of this order of elasmobranch tapeworms. Seussapex possesses what is arguably the most complex scolex seen thus far in the order. It is unique among lecanicephalideans in exhibiting a bipartite AO; all other genera either lack an AO (e.g. Aberrapex and Paraberrapex) or exhibit an AO that is composed of only a single unit. Furthermore, among the genera that exhibit primarily glandular tissue associated with their AO (i.e. Eniochobothrium, Healyum, Hornellobothrium, Polypocephalus, Quadcuspibothrium and some species of Anteropora) (see e.g. Jensen 2001, 2005, Jensen et al. 2011, Mojica et al. 2013), it is the only genus in which that tissue is organized into two, rather than a single compartment. Polypocephalus is worth mentioning in this context in some detail, for among lecanicephalidean genera, it rivals Seussapex in the complexity of its apical scolex features. The anteriormost part of its AO consists of a number of tentacles that can be completely invaginated into what essentially functions as a tentacular pouch located within the scolex proper (see Jensen 2005). In a few members of Polypocephalus, glandular compartments have also been reported. For example, in his illustration of Polypocephalus radiatus Braun, 1878, Braun (1878; plate XVI, fig. 3) labeled a structure at the base of the tentacular pouch as 'Drüsenmasse' (mass of glands). Similarly, Subhapradha (1951; p. 207) referred to the 'glandular complex' (figs. 1A,B, 4) in illustrations of Polypocephalus rhinobatidis Subhapradha, 1951. More recently, Jensen (2005; fig. 47A-C) illustrated a glandular-type region at the base of the tentacular pouch of Polypocephalus helmuti Jensen, 2005. While none of these glandular regions are organized in two compartments, the scolex of this genus most closely resembles that of Seussapex. Given this resemblance is also seen in proglottid anatomy, it is likely these two genera will be found to be closely related once a comprehensive phylogenetic analysis can be conducted.

Caira et al. (1999) standardized the terminology of the apical structures of lecanicephalideans, formally distinguishing the AMSP from the apical organ AO. These authors defined the AMSP as a region composed of tissue that is continuous with and not discrete from the scolex proper, and the $\mathrm{AO}$ as a region composed of tissue distinct from that of the scolex proper based on an external difference in microthrix pattern (i.e. an absence of spinitriches/ filitriches on the AO) and an internal difference in tissue type. This terminology was subsequently consistently applied to lecanicephalidean genera (see Jensen 2005, Cielocha and Jensen 2011, 2013, Jensen et al. 2011, Koch et al. 2012). However, our work with Seussapex suggests that the formerly held notion of Caira et al. (1999) that the presence of large spinitriches externally corresponds with the boundary between the AMSP and AO needs to be revised. Species of Seussapex exhibit a sharp transition in microthrix pattern that occurs within the AMSP with large spinitriches being present only on its more posterior regions. The only other lecanicephalidean that has been described as invaginating the anterior region of the AMSP into the scolex proper is Stoibocephalum arafurense Cielocha et Jensen, 2013 (see Cielocha and Jensen 2013).

In the past, cytochemical work performed on histological sections of adult and larval scoleces of elasmobranch tapeworms have resulted in some insight regarding the potential adhesive nature of particular tissues. The silver methenamine-periodic acid staining method was employed by McCullough and Fairweather (1989) to provide evidence for secretions consisting of glycoproteins in the tetraphyllidean Trilocularia acanthiaevulgaris Olsson, 1867. While the function of this material is still speculative, as noted by these authors, it may be involved in adhesion, proteolysis, strobilisation or protection. Caira et al. (2005) identified periodic acid-Schiff (PAS)-positive tissue in the scolex of the cathetocephalidean Sanguilevator yearsleyi Caira, Mega et Ruhnke, 2005 providing some evidence for the presence of glycoproteins or mucopolysaccharides as possible adhesive substances in this species. Among lecanicephalideans, the larva of an undescribed species of Polypocephalus was postulated to secrete glycoproteins with adhesive potential from its tentacles, as evidenced by the presence of tissues that stained 
positive for proteins and neutral mucosubstances (Brockerhoff and Jones 1995). In the present study, PAS staining indicated that the surface of the anterior knob-like part of the AO and the anterior glandular compartment of Seussapex likely contains glycogen or neutral mucosubstances, suggesting attachment to the mucosal surface may be of a chemical, rather than mechanical, nature. Additional studies are needed to identify the chemical composition of the glandular material in the AO compartments and to ascertain their function.

At this point, species of Seussapex are known to parasitize members of two families of batoids, the Dasyatidae (whiptail stingrays) and the Myliobatidae (eagle rays). However, their host associations within each of these families appear to be more restricted. As part of a survey of metazoan parasites of elasmobranchs of Borneo, as well as extensive collections of tapeworms from elasmobranchs from northern Australia, the Solomon Islands, Taiwan, Thailand and Vietnam, specimens representing 31 species in seven of the eight genera of Dasyatidae (sen$s u$ Naylor et al. 2012) were examined. These consisted of Dasyatis Rafinesque (5 spp.), Taeniurops Garman (1 sp.), Himantura (23 spp.), Urogymnus Müller et Henle (1 sp.), Neotrygon Castelnau (6 spp.), Taeniura Müller et Henle (2 spp.) and Pastinachus Rüppell (4 spp.). Among these stingray species, only Himantura species were found to host Seussapex (see Table 1). In addition to Himantura uarnak 2 (11 of 13 specimens infected), these were as follows: H. leoparda (2 of 2 specimens infected), H. pastinacoides 2 (1/1), H. uarnacoides (7/14), H. uarnak 1 (2/2), H. uarnak 3 (3/3), and H. undulata (1/3). Thus, it appears that, within the Dasyatidae, Seussapex is a parasite of species of Himantura only, with prevalences ranging from $30 \%$ to $100 \%$, but not all species of Himantura were found to be infected.

With respect to the Myliobatidae, Seussapex has been reported from only a single species of eagle ray in the genus Aetobatus. However, the host species determination for $S$. narinari remains problematic. Its type host was reported by MacCallum (1917; p. 53) as 'Aetobatis [sic] narinari, spotted sting ray' and the type locality was not given. This could be explained by the fact that, as stated in a footnote associated with the title of his publication (MacCallum 1917), MacCallum's specimen of S. narinari came from an animal at the New York Aquarium and United States Fish Commission Laboratory at Woods Hole. The type specimen is mounted on a slide with a specimen of the trypanorhynch Tetrarhynchus narinari MacCallum, 1917, now Kotorella pronosoma (Stossich, 1901) Euzet et Radujkovic, 1989; see Palm (2004). The slide label indicates 'Batavia Java' as the type locality. According to White et al. (2010) and Naylor et al. (2012), the whitespotted species of Aetobatus from the Indo-West and Central Pacific Oceans is Aetobatus ocellatus Kuhl, whereas the species name $A$. narinari is reserved for specimens of Aetobatus from the western Atlantic Ocean. Curiously, despite extensive sampling of cestodes from $A$. ocellatus from the Indo-West and Central Pacific Oceans over the last approx. 20 years, we have been unsuccessful in recollecting $S$. narinari. Hosts examined include a total of 23 specimens of $A$. ocellatus taken from across the distribution of this eagle ray: ten from northern Australia, eight from Borneo, two from the Solomon Islands and one each from Taiwan, Thailand and Vietnam; none of these animals were found to host Seussapex. These data, together with the fact that specimens of Seussapex were found to parasitize multiple species of Himantura at relatively high prevalence in these same waters, lead us to consider the host identification for $S$. narinari to be highly suspect. The search for the true host might in fact be futile for the incomplete nature of the only available specimen of $S$. narinari renders its definitive identification almost impossible.

The full diversity of Seussapex, beyond the two species treated herein, remains to be determined. As mentioned above, newly collected material examined in this study included specimens from seven species of Himantura. Subtle differences were observed among specimens of Seussapex from different species of Himantura. These included, for example, total length, number of proglottids, scolex length and sucker diameter, in addition to some variation in scolex morphology. However, the extreme variability in scolex form across specimens depending on state of retraction/protrusion and/or invagination/evagination of the various components of the scolex hampered unambiguous delimitation of species groups. Furthermore, specimens across host species were remarkably similar in proglottid anatomy and microthrix pattern. As a consequence, we have taken a conservative approach and have described only a single new species based on specimens from a single host species (i.e. Himantura uarnak 2 sensu Naylor et al. 2012) here. However, an effort was made to include as much regional and temporal variation as possible from this host species. Thus, specimens on which the description of $S$. karybares was based came from two localities and were collected six years apart (specimens with Collection Code 'AU' were collected in 1997, those with Collection Code 'CM03' were collected in 2003). So as to avoid both erroneously forcing oixenous host-specificity (sensu Caira et al. 2003) on the system and postulating unusually relaxed host specificity, we recommend using a combination of molecular sequence data and larger series of specimens from different host species than were available for this study to determine species boundaries in this group in the future.

Acknowledgements. We are grateful to Dr. Janine Caira for extensive comments on this manuscript, and for discussions and advice concerning homologous features and PAS staining. We extend our thanks to Richard Mounsey (formerly of Darwin Fisheries) for collections Himantura uarnak 2 from Buffalo 
Creek, Australia, Lyle Squire of Cairns Marine Aquarium Supply for collections of $H$. uarnak 2 from Weipa, Australia, and Janine Caira, Loren Caira, Gavin Naylor, Annie Lim, Mabel Manjaji-Matsumoto, Fahmi, and Dharmadi for collections in
Indonesian and Malaysian Borneo. This research was funded by the NSF BSI awards No. 0542941 and 0542846 (including an REU supplement), NSF PEET grants No. 9521943 and 0118882 , and an UGRA from the University of Kansas.

\section{REFERENCES}

Braun M. 1878: Zwei neue Bandwürmer. Arbeit. Zool.-Zootom. Inst. Würzburg, Neue Folge 4: 297-302.

Brockerhoff A., Jones M.K. 1995: Ultrastructure of the scolex and tentacles of the metacestode of Polypocephalus species (Cestoda: Lecanicephalidae) from the blue-swimmer crab Portunus pelagicus. Int. J. Parasitol. 25: 1077-1088.

Caira J.N., Jensen K., Healy C.J. 1999: On the phylogenetic relationships among tetraphyllidean, lecanicephalidean, and diphyllidean tapeworm genera. Syst. Parasitol. 42: 77-151.

Caira J.N., Jensen K., Healy C.J. 2001: Interrelationships among tetraphyllidean and lecanicephalidean cestodes. In: D.T.J. Littlewood and R. Bray (Eds.), Interrelationships of the Platyhelminthes. Taylor and Francis, London, pp. 135-158.

Caira J.N., Jensen K., Holsinger K.E. 2003: On a new index of host specificity. In: C. Combes and J. Jourdane (Eds.), Taxonomie, Ecologie et Evolution des Métazoaires Parasites. (Livre hommage à Louis Euzet). PUP Perpignan, Tome 1, pp. 161-201.

Caira J.N., Jensen K., Waeschenbach A., Olson P.D., Littlewood D.T.J. 2014: Orders out of chaos - molecular phylogenetics reveals the complexity of shark and stingray tapeworm relationships. Int. J. Parasitol. 44: 55-73.

Caira J.N., Mega J., Ruhnke, T.R. 2005: An unusual blood sequestering tapeworm (Sanguilevator yearsleyi n. gen., n. sp.) from Borneo with description of Cathetocephalus resendezi $\mathrm{n}$. sp. from Mexico and molecular support for the recognition of the order Cathetocephalidea (Platyhelminthes: Eucestoda). Int. J. Parasitol. 35: 1135-1152.

Chervy L. 2009: Unified terminology for cestode microtriches: a proposal from the International Workshops on Cestode Systematics in 2002-2008. Folia Parasitol. 56: 199-230.

Cielocha J.J., Jensen K. 2011: A revision of Hexacanalis (Cestoda: Lecanicephalidea) and description of Hexacanalis folifer $\mathrm{n}$. sp. from the zonetail butterfly ray, Gymnura zonura (Bleeker) (Rajiformes: Gymnuridae). Syst. Parasitol. 79: 1-16.

Cielocha J.J., Jensen K. 2013: Stoibocephalum n. gen. (Cestoda: Lecanicephalidea) from the sharkray, Rhina ancylostoma Bloch \& Schneider (Elasmobranchii: Rhinopristiformes), from northern Australia. Zootaxa 3626: 558-568.

Euzet L. 1994: Order Lecanicephalidea Wardle \& McLeod, 1952. In: L.F. Khalil, A. Jones and R.A. Bray (Eds.), Keys to the Cestode Parasites of Vertebrates. CABI, Wallingford, pp. 195-204.

JeNSEN K. 2001: Four new genera and five new species of lecanicephalideans (Cestoda: Lecanicephalidea) from elasmo-

Received 17 September 2013 branchs in the Gulf of California, Mexico. J. Parasitol. 87: 845-861.

JENSEN K. 2005: A monograph on the Lecanicephalidea (Platyhelminthes, Cestoda). Bulletin of the University of Nebraska State Museum 18: 1-241.

Jensen K., Nikolov P., Caira J.N. 2011: A new genus and two new species of Anteroporidae (Cestoda: Lecanicephalidea) from the darkspotted numbfish, Narcine maculata (Torpediniformes: Narcinidae), off Malaysian Borneo. Folia Parasitol. 58: 95-107.

Koch K.R., Jensen K., Caira J.N. 2012: Three new genera and six new species of lecanicephalideans (Cestoda) from eagle rays of the genus Aetomylaeus (Myliobatiformes: Myliobatidae) from northern Australia and Borneo. J. Parasitol. 98: 175-198.

MacCallum G.A. 1917: Some new forms of parasitic worms. Zoopathologica 1: 1-75.

McCullough J.S., Fairweather I. 1989: The fine structure and possible functions of scolex glands in Trilocularia acanthiaevulgaris (Cestoda, Tetraphyllidea). Parasitol. Res. 75: 575-582.

Mojica K.R., Jensen K., Caira J.N. 2013: Revision of Anteropora (Cestoda: Lecanicephalidean) and description of five new species from stingrays (Myliobatiformes: Dasyatidae) in Borneo. Raffles Bull. Zool. 61: 491-506.

Naylor G.J.P., Caira J.N., Jensen K., Rosana K.A.M., White W.T., LAST P.R. 2012: A DNA sequence-based approached to the identification of shark and ray species and its implications for global elasmobranch diversity and parasitology. Bull. Am. Mus. Nat. Hist. 367: 1-262.

Palm H.W. 2004: The Trypanorhyncha Diesing, 1863. PKSPL-IPB Press, Bogor, 710 pp.

Sheehan D.C., Hrapchak B.B. 1987: Theory and Practice of Histotechnology, Second Edition. Battelle Memorial Institute, Columbus, Ohio, 481 pp.

Subhapradha C.K. 1951: On the genus Polypocephalus Braun, 1878 (Cestoda), together with descriptions of six new species from Madras. Proc. Zool. Soc. London 121: 205-235.

White W.T., Last P.R., Naylor G.J.P., Jensen K., Caira J.N. 2010: Clarification of Aetobatus ocellatus (Kuhl, 1823) as a valid species, and a comparison with Aetobatus narinari (Euphrasen, 1790) (Rajiformes: Myliobatidae). In: P.R. Last, W.T. White and J.J. Pogonoski (Eds.), Descriptions of New Sharks and Rays from Borneo. CSIRO Marine and Atmospheric Research Paper 032, Hobart, pp. 141-164. 